\title{
REDUCTION OF ANXIETY IN CHILDREN FACING HOSPITALIZATION BY PLAY THERAPY: ORIGAMI AND PUZZLE IN LAMPUNG-INDONESIA
}

\author{
Teguh Pribadi', Devita Elsanti ${ }^{2}$, Andri Yulianto ${ }^{3}$
}

\begin{abstract}
${ }^{1}$ Lecturer in Faculty of Medicine, Nursing and Health Sciences Malahayati University, BandarLampung, Indonesia. Email: teguh@malahayati.ac.id

2Lecturer in Nursing Departement, Health Science Faculty, University Muhammadiyah Purwokerto, Indonesia. Email: devitaelsanti@ump.ac.id

${ }^{3}$ Lecturer in Nursing Study Program, Institute of Health Sciences (STIKES) Muhammadiyah Pringsewu, Indonesia. Email: andrii.yuliianto@gmail.com
\end{abstract}

\begin{abstract}
Background: At the time of hospitalization of children, they feel uncomfortable such as an anxiety. Statistics data base in 2010 in Indonesia reported that in 35 of 420 children has stress during hospitalization. However during hospitalization the children must be cooperate in treatment for recovery.

Purpose: Knowing the influence of play therapy: origami and puzzles for reducingan anxiety to children at Pertamina Bintang Amin Hospital, Bandar Lampung-Indonesia 2018.

Methods: Quantitative researchwith design used quasi-experimental. The study population was all patient at pediatric ward at Pertamina Bintang Amin Hospital, Bandar Lampung Indonesiawith 50 children as sampleand used instruments: Zung Self-Rating Scale (ZSRAS) and Tailor Manifest Anxiety Scale (T-MAS).The statistical analysis used an independent $T$ test.

Results: Finding significane different of the total score of anxiety before and after play therapy (before play therapy: origami and puzzle were 20.2and20.7) and (after play therapy: origami and puzzle were 14.9 and 12.7). The total score rates was descrease of 5.27 in origami therapy and of 8.0 in puzzle therapy with $p$-value of 0.000 .

Conclusion: There was differences effect in both of play therapy: origami and puzzle to reducing an anxiety.It is suggestions to management hospital to provide play therapy such as origami and puzzle as an alternative therapy to reduce anxiety to the children due to hospitalization and thus supporting the healing process.
\end{abstract}

Keywords: Play therapy, origami, puzzle, anxiety, children

\section{INTRODUCTION}

Hospitalization is a process for a reason that is planned or emergency requires the child to stay in the hospital, undergo therapy and care until his return home. Children who are sick and must be hospitalized will experience a difficult time because they are unable to practice as usual. Environment and foreigners, care and various procedures undertaken by children are the main sources of stressors, disappointment and anxiety, especially for children who are first hospitalized (Wahyuningrum, \& Khusnal, 2015).

Phenomena of separation and experience of hospitalized children shows that when children are hospitalized they will experience changes in emotional status, as well as parents. This phenomenon of separation causes children to behave inappropriately, such as crying, aggressiveness, withdrawal and hypo-active (Rini, 2013). In the life of a child, in a hospital the child must face an unfamiliar environment and an unknown caregiver, often the child has a procedure that causes pain, loss of independence and various unknowns, the child's interpretation of the child's event and response to experience while at home pain will be assumed to be a bad experience, which is indirectly affects the level of development of children. At such times the child's feelings will be full of emotional burdens such as anxiety, fear, feelings of inferiority, feelings of anger, depression, feelings of helplessness, excessive dependence on others and not being able to think well (Utami, 2011).

The reason that children are hospitalized in the United States from the highest to the lowest is diseases related to the respiratory system (pneumonia, asthma, acute bronchitis), mental health conditions (depression and bipolar disorder), surgical diagnosis (appendixitis), dehydration (which often becomes complications of gastroenteritis), epilepsy, urinary tract infections and influenza (Yu, Wier \& Elixhauser, 2009).

The morbidity rate of children in Indonesia who are hospitalized is quite high, which is around 35 
Malahayati International Journal of Nursing and Health Science, Volume 01, No.1, March 2018: 29-35 REDUCTION OF ANXIETY IN CHILDREN FACING HOSPITALIZATION BY PLAY THERAPY: ORIGAMI AND PUZZLE IN LAMPUNG-INDONESIA

per 100 children, which is indicated by the full space of children both government hospitals and private hospitals (Putri, 2017).

When children are hospitalized, various feelings emerge, one of which is anxiety (Apriany, 2013). Statistics data base in 2010 in Indonesia reported that in 35 of 420 children has stress during hospitalization. However during hospitalization the children must be cooperate in treatment for recovery.

For this reason, play therapy and good parent cooperation can minimize or reduce children's anxiety during treatment (Handayani \& Puspitasari (2010)). Playing is the work of children in all ages and plays an important role in their development. Playing is also a fun activity for children and one of the most important tools for managing anxiety due to hospitalization creates a crisis in a child's life, and because the situation is often accompanied by excessive anxiety, children need to play to release the fear and anxiety they experience coping tools in dealing with stress. Playing is very important for the mental, emotional and well-being of the child, such as the need for development and the need to play, not to stop when the child is sick or cared for by a child in the hospital (Kusumaningrum, 2010).

The purpose of applying play therapy to children in hospitals is for children to continue normal growth and development during treatment, in order to express children's thoughts and fantasies, so that children can develop creativity through the right playing experience and so that children can adapt effectively to the new environment namely hospitals so that children's anxiety due to hospitalization can be reduced due to play therapy (Widianti, 2011).

In addition play therapy will release the child from the tension and anxiety experienced. Because playing with children will be able to divert the pain in the game (distraction) and relaxation through the pleasure of playing. As a result of the distraction and relaxation that occurs, children who experience anxiety eventually become less anxious (Supartini, 2014).

Playing during school is an activity that is an important part of development in the first years of childhood. Through playing, children can show what they feel during hospitalization because by playing games children can forget the pain. Considerations such as the characteristics and needs of playing school-age children during hospitalization, the limitations of pediatric patients for mobilization, costs, special rooms and limited nursing personnel, playing with coloring can be an option to help reduce children's anxiety (Zulfa, 2017).

Selection of puzzle games in this game therapy because puzzles are one of the educational games that can optimize children's abilities and intelligence. Playing puzzle is useful for sharpening the brain, practicing eye and hand coordination, practicing reasoning, exercising patience and providing knowledge (Alfiyanti, 2010). From the benefits of the game, it is expected that children will not focus on their illness or foreign environment.

This type of puzzle game is used in this study, because puzzles can improve children's thinking power. Puzzle games include multifunctional games, namely games that contain many functions or benefits. In addition, puzzle games include games that can increase cognitive power, because children will play by focusing their attention on the game. Puzzle games are chosen as a form of game therapy, because children who play puzzles focus their attention on the game and reduce other activities (Lilis, 2016).

In addition, origami methods can be used as a therapy to reduce anxiety due to hospitalization, origami play therapy provides an opportunity for children to make various shapes from the results of folding paper and at this age, children will feel proud of something that has been produced. This is in accordance with the theory of the stage of psychosocial development of school children which suggests that school children begin to develop their desires by exploring the surrounding environment. Children will also feel satisfied and proud of their ability to produce something as their achievement.the anxiety stressor in the form of losing control can be overcome then the level of anxiety in children can decrease (Sandy, 2015).Origami playing is a game that can be applied to preschoolers. By folding paper into an ornamental object will develop creativity and give pleasure to children so that it will help children

Teguh Pribadi' Lecturer in Faculty of Medicine, Nursing and Health Sciences Malahayati University, Bandar Lampung, Indonesia. Email: teguh@malahayati.ac.id

Devita Elsanti ${ }^{2}$ Lecturer in Nursing Departement, Health Science Faculty, University Muhammadiyah Purwokerto, Indonesia. Email: devitaelsanti@ump.ac.id

Andri Yulianto ${ }^{3}$ Lecturer in Nursing Study Program, Institute of Health Sciences (STIKES) Muhammadiyah Pringsewu, Indonesia. Email: andrii.yuliianto@gmail.com 
Malahayati International Journal of Nursing and Health Science, Volume 01, No.1, March 2018: 29-35 REDUCTION OF ANXIETY IN CHILDREN FACING HOSPITALIZATION BY PLAY THERAPY: ORIGAMI AND PUZZLE IN LAMPUNG-INDONESIA

lower the mind anxious, afraid, sad, tense and painful. Origami can be used to teach skills in preschoolers because the movement of folding paper in addition to developing creativity can also develop the motor nervous system (Lestari, 2015). Origami is a game that can be applied to preschoolers who have undergone hospitalization because it is in accordance with the principles of the game that is in the hospital, which unrequire much energy, is short, simple, safe and inexpensive.

Based on the results of a preliminary study conducted withof 50 children in November 2016, finding of 37 of 50 children experienced anxiety, with an average anxiety reaction like do not want to be hospitalized, often cry, refuse to eat and often ask to go home because they are afraid of strangers (health workers, especially nurses) and the treatment it self. The nurses staff said that never apply play therapy. The some children refuses hospitalization for various reasons, one of them being anxious about being hospitalized and would like to go outpatient.

\section{RESEARCH METHODS}

The type of research was quantitative with design used quasi-experimental. The population was all patient at pediatric ward at Pertamina Bintang Amin Hospital, Bandar Lampung Indonesiawith 50 children as sample and used instruments: Zung Self-Rating Scale (ZSRAS) and Tailor Manifest Anxiety Scale (T-MAS).The statistical analysis used an independent $T$ test.

\section{RESEARCH RESULTS}

Table 1. The Scores of Anxiety Levels in Children Before Giving Play Therapy

\begin{tabular}{llll}
\hline $\begin{array}{l}\text { Level of anxiety before play } \\
\text { therapy: }\end{array}$ & Mean & Sdt Dev & Min-Max \\
& & & \\
\hline Playing Origami & 20.2 & 1.74 & $17-23$ \\
Playing Puzzle & 20.7 & 2.72 & $17-26$ \\
& & & \\
\hline
\end{tabular}

Table 2. The Scores of Anxiety Levels in Children After Giving Play Therapy

\begin{tabular}{llll}
\hline $\begin{array}{l}\text { Level of anxiety after play } \\
\text { therapy: }\end{array}$ & Mean & Sdt Dev & Min-Max \\
& & & \\
\hline $\begin{array}{l}\text { Playing Origami } \\
\text { Playing Puzzle }\end{array}$ & 14.9 & 1.67 & $12-17$ \\
& 12.7 & 1.54 & $10-15$
\end{tabular}

Teguh Pribadi' Lecturer in Faculty of Medicine, Nursing and Health Sciences Malahayati University, Bandar Lampung, Indonesia. Email: teguh@malahayati.ac.id

Devita Elsanti ${ }^{2}$ Lecturer in Nursing Departement, Health Science Faculty, University Muhammadiyah Purwokerto, Indonesia. Email: devitaelsanti@ump.ac.id

Andri Yulianto ${ }^{3}$ Lecturer in Nursing Study Program, Institute of Health Sciences (STIKES) Muhammadiyah Pringsewu, Indonesia. Email: andrii.yuliianto@gmail.com 
Malahayati International Journal of Nursing and Health Science, Volume 01, No.1, March 2018: 29-35 REDUCTION OF ANXIETY IN CHILDREN FACING HOSPITALIZATION BY PLAY THERAPY: ORIGAMI AND PUZZLE IN LAMPUNG-INDONESIA

Table 3. Difference Scoresof Anxiety Levels in Children Before and After Conducting Play Therapy

Decrease scores of Mean Sdt Dev Min-Max
Anxiety Levels:

\begin{tabular}{llll}
\hline Playing Origami & 5.27 & 1.75 & $3-8$ \\
Playing Puzzle & 8.00 & 1.96 & $5-12$
\end{tabular}

\section{Analysis Bivariate}

Table 4. The Influence of Play Therapy: Origami and Puzzles on the Anxiety in Children

\begin{tabular}{lcccccc}
\hline Variable & Mean & SD & SE & $\mathbf{t}_{\text {count }}$ & p-value & $\mathbf{N}$ \\
\hline Playing Puzzle & 8.00 & 1.96 & 0.507 & 4.023 & 0.000 & 15 \\
$\begin{array}{l}\text { Playing } \\
\text { Origami }\end{array}$ & 5.27 & 1.75 & 0.452 & & & 15 \\
\hline
\end{tabular}

Table above shows that the influence of play therapy and scores of anxiety levels in childrenwas a decrease afterplay therapy (puzzle of 8.00 with a standard deviation of 1.96 ) and (Origami of 5.27 with a standard deviation of 1.75). The results of statistical tests, it is found that $\mathrm{t}$ count $=4.023$ and $\mathrm{t}$

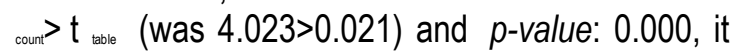
can be concluded there was significane effect of both plays therapy and significane difference effectof boththerapy to the anxiety in children who hosilalized at Pertamina Bintang Amin Hospital Bandar Lampung-Indonesia 2018.

\section{DISCUSSION}

Theresults of this study showed that the response of children in anxiety due to hospitalization in the Pertamina Hospital Bintang Amin Hospital Bandar Lampung on 15 respondents was very effective to reducing anxiety levels. This study was similar result with other previous research which is showed a positive and significant effect of play therapy: puzzle in children during hospitalization (Kaluas, Ismanto, \& Kundre, 2015).

Puzzle play therapy was more effectivethan origami play therapy to reduce anxiety in children due to hospitalization. Many benefits of puzzles play therapyinstead of origami, wherefore of training fine motor skills as well as eye-hand coordination, increasing motoric speed of children, understanding the atmosphere of competition, increasing awareness of space, recognizing forms and combining them.

Playing is the work of children in all ages and plays an important role in their development. Playing is also a fun activity for children and one of the most important tools for managing anxiety due to hospitalization creates a crisis in a child's life, and because the situation is often accompanied by excessive anxiety, children need to play to release the fear and anxiety they experience coping tools in dealing with stress. Playing is very important for the mental, emotional and well-being of the child, such as the need for development and the need to play, not to stop when the child is sick or cared for by a child in the hospital (Wong, 2008).

The purpose of applying play therapy to children in hospitals is for children to continue normal growth and development during treatment, in order to express children's thoughts and fantasies, so that children can develop creativity through the right playing experience and so that children can adapt effectively to the new environment namely hospitals so that children's

Teguh Pribadi' Lecturer in Faculty of Medicine, Nursing and Health Sciences Malahayati University, Bandar Lampung, Indonesia. Email: teguh@malahayati.ac.id

Devita Elsanti ${ }^{2}$ Lecturer in Nursing Departement, Health Science Faculty, University Muhammadiyah Purwokerto, Indonesia. Email: devitaelsanti@ump.ac.id

Andri Yulianto ${ }^{3}$ Lecturer in Nursing Study Program, Institute of Health Sciences (STIKES) Muhammadiyah Pringsewu, Indonesia. Email: andrii.yuliianto@gmail.com 
Malahayati International Journal of Nursing and Health Science, Volume 01, No.1, March 2018: 29-35 REDUCTION OF ANXIETY IN CHILDREN FACING HOSPITALIZATION BY PLAY THERAPY: ORIGAMI AND PUZZLE IN LAMPUNG-INDONESIA

anxiety due to hospitalization can be reduced due to play therapy (Adriana, 2013).

In addition play therapy will release the child from the tension and anxiety experienced. Because playing with children will be able to divert the pain in the game (distraction) and relaxation through the pleasure of playing. As a result of the distraction and relaxation that occurs, children who experience anxiety eventually become less anxious (Deswita, 2016).

Playing during school is an activity that is an important part of development in the first years of childhood. Through playing, children can show what they feel during hospitalization because by playing games children can forget the pain. Considerations such as the characteristics and needs of playing school-age children during hospitalization, the limitations of child patients for mobilization, costs, special rooms and limited nursing personnel, playing with coloring can be an option to help reduce children's anxiety (Wong, 2008).

Selection of puzzel games in this game therapy because puzzels are one of the educational games that can optimize children's abilities and intelligence. Puzzel is useful for sharpening the brain, practicing eye and hand coordination, practicing reasoning, exercising patience and providing knowledge and the benefits of the game, it is expected that children will not focus on their illness or foreign environment (Alfiyanti, 2010)

This type of puzzle game is used in this study, because puzzles can improve children's thinking power. Puzzle games include multifunctional games, namely games that contain many functions or benefits. In addition, puzzle games include games that can increase cognitive power, because children will play by focusing their attention on the game. Puzzle games are chosen as a form of game therapy, because children who play puzzles focus their attention on games and reduce other activities (Fatimah, 2012).

In addition, origami methods can be used as a therapy to reduce anxiety due to hospitalization. Giving origami play therapy to school-aged patients treated in hospitals provides benefits for developing children's fine motor skills, while stimulating children's creativity. Origami play therapy provides an opportunity for children to make various shapes from the results of folding paper and at this age, children will feel proud of something that has been produced. This is in accordance with the theory of the stage of psychosocial development of school children which suggests that school children begin to develop their desires by exploring the surrounding environment. Children will also feel satisfied and proud of their ability to produce something as their achievement. Feeling proud to help children improve their role during the hospitalization process so that the feeling of loss of control because of restrictions on activities in children can be overcome / eliminated, when an anxiety stressor in the form of loss of control can be overcome, the level of anxiety in children can decrease (Agustina \& Puspita, 2017).

Origami play is a game that can be applied to preschoolers. By folding paper into ornamental objects will develop creativity and give pleasure in children so that it will help children lower their anxious, fearful, sad, tense and painful thoughts. Origami games can be used to teach skills in preschoolers because the paper folding movement can develop creativity and can develop the motor nervous system. origami is a game that can be applied to preschoolers who experienced a hospitalization due in accordance with the principles of the game that was in the hospital that do not require as much energy, in short, simple, safe and in expensive (Damayanti, 2011)

\section{CONCLUSION}

Decreasing the score of anxiety levelsin children between before and after being given therapy and there were differences of influence in both of play therapy

\section{SUGGESTIONS}

Hospital institutions to be provide and facilitations play therapy to the children andnurses could applyplay therapy: origami or puzzle as an alternative therapy to reduce the anxiety in children due to hospitalization and supporting in the healing process.

The next researcher should further improve the results of this study by controlling other factors that influence this research, including the hospital

Teguh Pribadi' Lecturer in Faculty of Medicine, Nursing and Health Sciences Malahayati University, Bandar Lampung, Indonesia. Email: teguh@malahayati.ac.id

Devita Elsanti ${ }^{2}$ Lecturer in Nursing Departement, Health Science Faculty, University Muhammadiyah Purwokerto, Indonesia. Email: devitaelsanti@ump.ac.id

Andri Yulianto ${ }^{3}$ Lecturer in Nursing Study Program, Institute of Health Sciences (STIKES) Muhammadiyah Pringsewu, Indonesia. Email: andrii.yuliianto@gmail.com 
Malahayati International Journal of Nursing and Health Science, Volume 01, No.1, March 2018: 29-35 REDUCTION OF ANXIETY IN CHILDREN FACING HOSPITALIZATION BY PLAY THERAPY: ORIGAMI AND PUZZLE IN LAMPUNG-INDONESIA

environment such as difference hospital (goverment or private hospital) and similar ward, for example the children's ward in difference class, so that optimal research results are obtained.

\section{REFERENCES}

Agustina, E., \& Puspita, A. (2017). Pengaruh PemberianTerapi Bermain Mewarnai GambarTerhadap Penurunan Tingkat kecemasan Anak Prasekolah Yang Rawat Inap (Studi Experimental Di Ruang Nusa Indah Rumah Sakit Umum Daerah Pare Tahun 2010).Jurnal Akp, 1(2).

Alfiyanti, N. (2010). Upaya Meningkatkan Daya Pikir Anak Melalui Permainan Edukatif.

Apriany, D. (2013). Hubungan Antara Hospitalisasi Anak Dengan Tingkat Kecemasan OrangTua. Jurnal Keperawatan Soedirman, 8(2).

Deswita, D. (2016). Perbedaan Pengaruh Terapi Bermain Mewarnai Gambar Dengan Bermain Puzzle Terhadap Kecemasan Anak Usia Prasekolah Di Irna Anak Rsup Dr. M. Djamil Padang. Ners Jurnal Keperawatan, 9(1), 13-17.

Handayani, R. D., \& Puspitasari, N. P. D. (2010). Pengaruh Terapi BermainTerhadap Tingkat Kooperatif Selama Menjalani Perawatan Pada Anak Usia Pra Sekolah (3-5 Tahun) Di Rumah Sakit Panti Rapih Yogyakarta. Jurnal Kesehatan Surya Medika Yogyakarta.

Kaluas, I., Ismanto, A. Y., \& Kundre, R. M. (2015).Perbedaan Terapi Bermain Puzzle Dan Bercerita Terhadap Kecemasan Anak Usia Prasekolah (3-5 Tahun) Selama Hospitalisasi Di Ruang Anak RS TK. III. Rw Mongisidi Manado.Jurnal Keperawatan, 3(2).
Kusumaningrum, A. (2010). Aplikasi Dan Strategi Konsep Family Centered Care Pada Hospitalisasi Anak Pra Sekolah. Jurnal Kedokteran Dan Kesehatan, 42(Iv).

Lestari, W. (2015).Pengaruh Bermain Origami Terhadap Kecemasan Anak Usia Pra Sekolah Yang Mengalami Hospitalisasi Di Ruang Mawar RSUD Kraton Pekalongan. Fikkes, 8(1).

Lilis, R. (2016). Ketersediaan Alat Permainan Edukatif (APE) Di TK Se-Kecamatan Ngampilan Kota Yogyakarta (Doctoral Dissertation, Paud).

Notoatmodjo, S. (2010). Metodologi Penelitian Kesehatan.

Putri, D. K. (2017).Pengaruh Terapi Bermain Terhadap Tingkat Kecemasan Anak Akibat Hospitalisasi Pada Anak Usia Pra Sekolah Di Bangsal Melati RSUD Dr. Soedirman Kebumen (Doctoral Dissertation, Stikes Muhammadiyah Gombong).

Rini, D. M. (2013).Hubungan Penerapan A traumatic Care Dengan Kecemasan Anak Prasekolah Saat Proses Hospitalisasi Di RSU Dr. H. Koesnadi Kabupaten Bondowoso.

Sandy, D. A. (2015).Pengaruh Terapi Bermain Origami Terhadap Tingkat Kecemasan Anak Usia Prasekolah Akibat Hospitalisasi Diruang Rawat Inap Anak (Cempaka) RSUD Wates Kulon Progo (Doctoral Dissertation, Stikes Jenderal Achmad Yani Yogyakarta).

Sugiyono, P. (2015). Metode Penelitian Kombinasi (Mixed Methods). Bandung: Alfabeta.

Supartini, Y. (2014). Buku Ajar Konsep.

Teguh Pribadi' Lecturer in Faculty of Medicine, Nursing and Health Sciences Malahayati University, Bandar Lampung, Indonesia. Email: teguh@malahayati.ac.id

Devita Elsanti ${ }^{2}$ Lecturer in Nursing Departement, Health Science Faculty, University Muhammadiyah Purwokerto, Indonesia. Email: devitaelsanti@ump.ac.id

Andri Yulianto ${ }^{3}$ Lecturer in Nursing Study Program, Institute of Health Sciences (STIKES) Muhammadiyah Pringsewu, Indonesia. Email: andrii.yuliianto@gmail.com 
Malahayati International Journal of Nursing and Health Science, Volume 01, No.1, March 2018: 29-35 REDUCTION OF ANXIETY IN CHILDREN FACING HOSPITALIZATION BY PLAY THERAPY: ORIGAMI AND PUZZLE IN LAMPUNG-INDONESIA

Utami, P. A. (2011). Pengaruh Pendidikan Kesehatan Pencegahan Perpisahan Orang Tua Terhadap Tingkat Kecemasan OrangTua Saat Anak Hospitalisasi Di RSU PKU Muhammadiyah Yogyakarta. FKIK (IImu Keperawatan), 7(7).

Wahyuningrum, I., \& Khusnal, E. (2015). Pengaruh Cerita Melalui Audiovisual Terhadap Tingkat Kecemasan Anak Usia Prasekolah Yang Mengalami Hospitalisasi Di RSU PKU Muhammadiyah Bantul (Doctoral Dissertation, Stikes aisyiyah Yogyakarta).
Widianti, C. R. (2011). Pengaruh Senam Otak Terhadap Kecemasan Akibat Hospitalisasi Pada Anak Usia Prasekolah Di Rumah Sakit Panti Rapih Yogyakarta (Doctoral Dissertation, Tesis. Depok: Universitas Indonesia).

Yu, H., Wier, L. M., \& Elixhauser, A. (2009). Hospital Stays For Children. Hcup Statistical Brief\# 118. 2011. Agency For Healthcare Research And Quality. Rockville Md.

Zulfa, F. (2017).Kesukaan Pemilihan Warna Dalam Mewarnai Gambar Pada Anak Kelompok B Di TK Gugus I Timbulharjo (Doctoral Dissertation, Paud).

Teguh Pribadi' Lecturer in Faculty of Medicine, Nursing and Health Sciences Malahayati University, Bandar Lampung, Indonesia. Email: teguh@malahayati.ac.id

Devita Elsanti ${ }^{2}$ Lecturer in Nursing Departement, Health Science Faculty, University Muhammadiyah Purwokerto, Indonesia. Email: devitaelsanti@ump.ac.id

Andri Yulianto ${ }^{3}$ Lecturer in Nursing Study Program, Institute of Health Sciences (STIKES) Muhammadiyah Pringsewu, Indonesia. Email: andrii.yuliianto@gmail.com 